
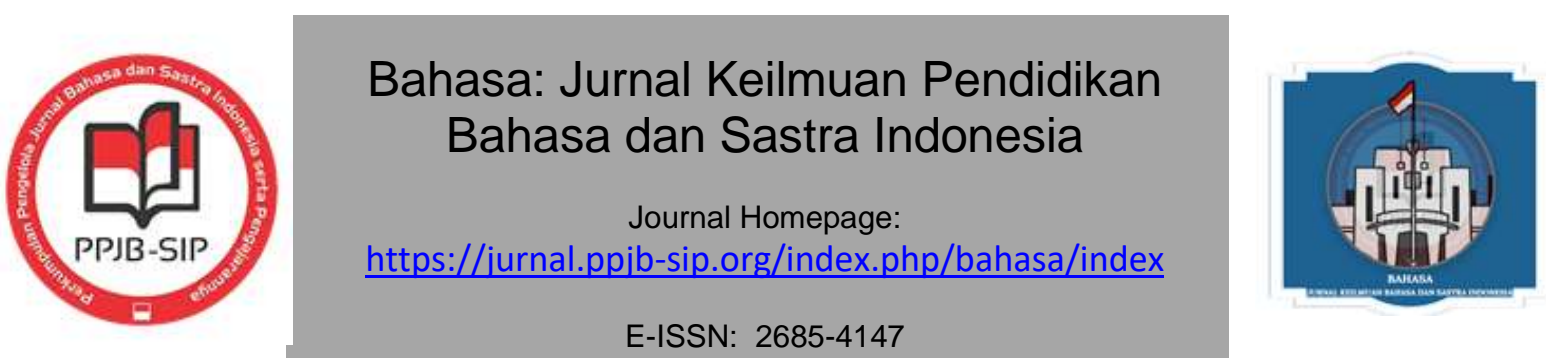

\title{
COVID-19 AND LITERATURE, FORMS OF SELF-ACTUALIZATION AND TEACHER DEVELOPMENT IN TOURISM, ARTS AND CULTURE
}

\section{COVID-19 DAN SASTRA, BENTUK AKTUALISASI DIRI DAN PENGEMBANGAN GURU DALAM PARIWISTA, KESENIAN DAN KEBUDAYAAN}

\author{
Maryelliwati ${ }^{1}$, Hari Adi Rahmad ${ }^{2}$ \\ ${ }^{1}$ ISI Padangpanjang ${ }^{2}$ STKIP Meranti \\ email: ${ }^{1}$ maryelliwati@gmail.com, ${ }^{2}$ hariadirahmad31@gmail.com
}

\begin{abstract}
The concept that underlies the learning of cultural arts is absolute for teachers which is based on meeting the needs of students in studying cultural arts in schools. The needs of these students, if it is related to the context of the development of the community's outlook on life, because after all students will eventually return to live and play a role in the social environment. The development of cultural arts for teachers is an important thing, especially during the corona period is a form of Higher Education Tri Dharma that must be done. The result is that the teacher is able to teach and understand and understand what the teacher needs as a capital to continue to exist, especially during the corona pandemic.
\end{abstract}

Keywords: Art, Culture, Teacher

\begin{abstract}
Konsep yang mendasari pembelajaran seni budaya adalah mutlak bagi guru yang didasarkan pada pemenuhan kebutuhan apa yang perlu bagi peserta didik dalam mempelajari seni budaya di sekolah. kebutuhan peserta didik ini, jika dikaitkan konteks perkembangan pandangan hidup masyarakat, karena bagaimana pun peserta didik pada akhirnya akan kembali hidup dan berperan dalam lingkungan bermasyarakat. Pengembangan seni budaya kepada guru merupakan suatu hal yang penting apalagi pada masa corona adalah salah bentuk Tri Dharma Perguruan Tinggi yang harus dilakukan. Hasilnya dalah guru mampu mengajarkan dan memahami serta mengerti seperti apa yang dibutuhkan guru sebagai modal untuk tetap eksis, apalagi pada masa pandemi corona.
\end{abstract}

Kata kunci: Seni, Budaya, Guru

\section{INTRODUCTION}

National education aims to develop the potential of students to become human beings who believe and fear God Almighty, have noble character, are healthy, knowledgeable, competent, creative, independent, and become democratic and responsible citizens (Law Number 20 years) (Gunawan:2012). To realize the goals of national education effectively and efficiently, quality education is needed. Quality education is education that can develop all the potential of

Received 13-07-2020, Accepted 071-08-2020

https:doi.org/10.26499/bahasa.v2i3.53

Published By: Perkumpulan Pengelola Jurnal Bahasa dan Sastra Indonesia (PPJB-SIP) 

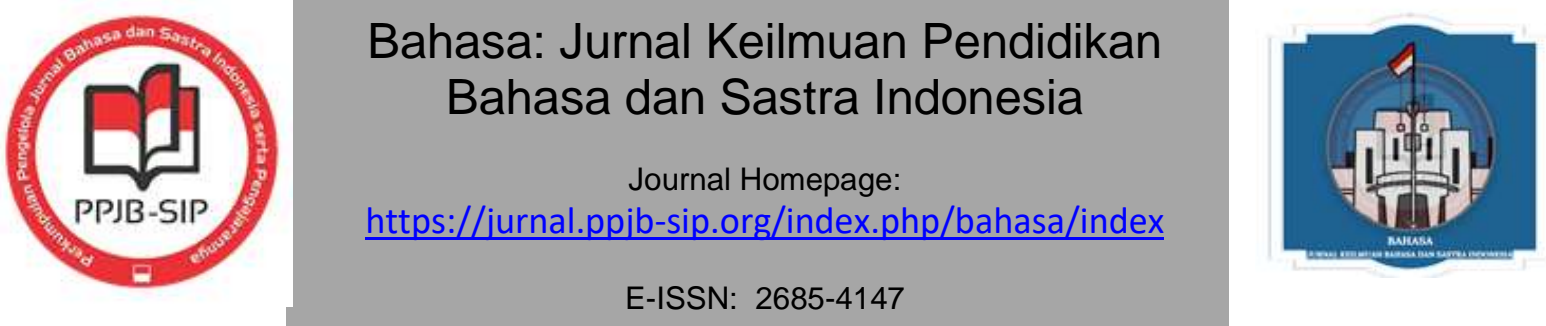

students so as to form human character, intelligent human being both intellectually, emotionally and spiritually (Sukring:2016).

In terms of the growth or development of art education itself, it changes in the context of the expected goals and implementation of art learning. as a brief overview of these developments such as; From the perspective of history, art education that was formerly outside of school then continues or is pursued in schools, where starting from communities, studios, apprenticeships, with the term inheritance, are now also found in formal government-supported educational institutions which are interpreted as academic education for the goal of supporting child maturity. In studying the function of art, it can be realized that art education in schools is a strategic part for students (Fitriani:2014). If further review can also be clarified into 2, among others; the first is art in the sense of essential justification, which is art education to improve or develop students' abilities related to the problem or field of study of art itself. The second is art in the sense of contextual justification, in this case art education becomes a medium or tool to help achieve the growth and development of the personality of students (non-art). Terms like selfactualization and validation are thrown around a lot these days; as our culture continues to move more and more towards individual celebration, these phrases are often used as compelling descriptions for self-realization and affirmation. Art can also be seen as joining "self" with "others", in communicating with himself, he can also communicate with others through the use of metaphors and allegories (devices that allow free expression, and thus represent forms of selfcommunication) (Nurgiantroro:2018). It creates a union between self and audience, dialogue that goes both ways simultaneously while creating epiphanies in both the subject (artist) and object (audience). Art depends on the existence of this library to be interpreted properly. This evocative metaphor is used to describe his own peak experience, and in doing so he creates a communication between himself and his audience that enables him to self-actualize like an example of tertiary need.

The function of art education can increase creativity(Suhaya:2016). Art can increase the ability to appreciate. Art education can develop imagination, creativity and artistic and intellectual abilities. From this it can be concluded that art education has a main function as a tool or media of education as well as a means of developing abilities in the art field itself. The study of the function of art above can realize that art education in schools is a strategic part for students. If further review can also be clarified into 2, among others; the first is art in the sense of essential justification, which is art education to improve or develop students' abilities related to the problem or field of study of art itself. The second is art in the sense of contextual justification, in this case art education becomes a medium or tool to help achieve the growth and development of the personality of students.

The essence of the 2 functions of art can be used as a reference in compiling a program for implementing art learning in schools. In the process, the teacher will be motivated about art and culture, but because the time is not optimal during the teaching and learning period and 

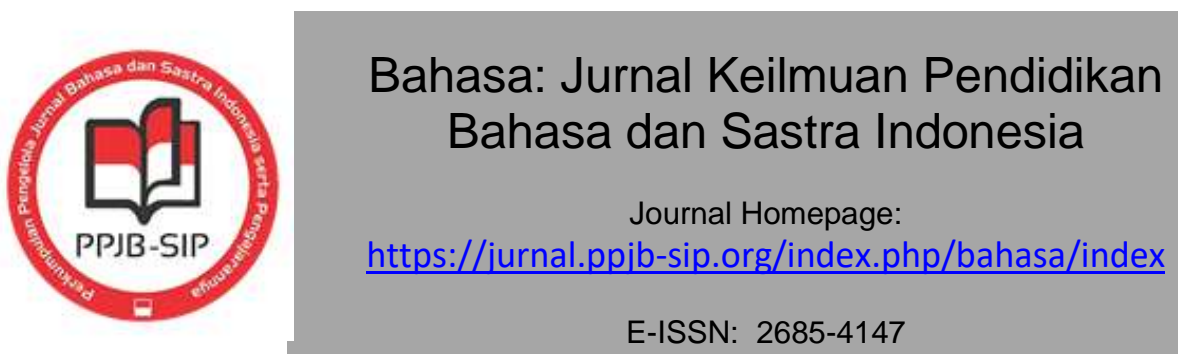

E-ISSN: $2685-4147$

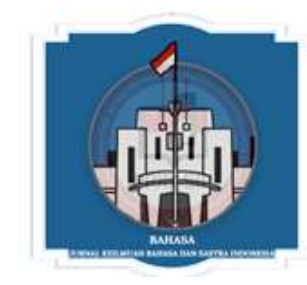

added to the Covid-19 atmosphere, the teacher needs to appreciate and practice art. So that art education includes aesthetic education which is very useful for students in Nasyatul Aisyiyah Kindergarten, Mungka. So, therefore, this research is worth researching and exploring the relationship.

\section{METHODS}

The method used is descriptive, which is trying to solve or answer the problems currently facing the situation. The descriptive method has many benefits, especially in order to make various improvements. A research or dedication carried out on a particular teaching method problem, for example, can reveal various aspects, especially in terms of goodness and weakness, as well as to what extent the teaching and learning process method (PBM) for a particular field of study. This method is carried out by taking the steps of collecting, classifying, and analyzing or processing data, making conclusions and reports; with the main objective to make an objective description of a situation in a description of the situation (Maryelliwati et al:2020). After that steps are taken so that the service process can run well and can be useful for teachers.

\section{RESULTS AND DISCUSSION}

In the future, a teacher must be able to set an example. In the middle, the teacher is required to create ideas, and from behind, the teacher has an obligation to provide encouragement and direction. Currently, the world is in the era of the industrial revolution 4.0, which means that the development of information technology can no longer be separated from human life in the 21 st century. As a driving force in the world of education, teachers are in the forefront. It is the teacher who is in direct contact with students, as a controller as well as a guide for the generation of the nation who will place themselves as part of the advancement of the digital era.

Therefore, teachers must be millennial and continue to gain knowledge, or they will be left behind. In studying the function of art, it can be realized that art education in schools is a strategic part for students. If further review can also be clarified into 2, among others; the first is art in the sense of essential justification, which is art education to improve or develop students' abilities related to the problem or field of study of art itself. The second is art in the sense of contextual justification, in this case art education becomes a medium or tool to help achieve the growth and development of students' personalities. Art can increase the ability to appreciate. Art education can develop imagination, creativity and artistic and intellectual abilities. From this it can be concluded that art education has a main function as a tool or media of education as well as a means of developing abilities in the art field itself. 

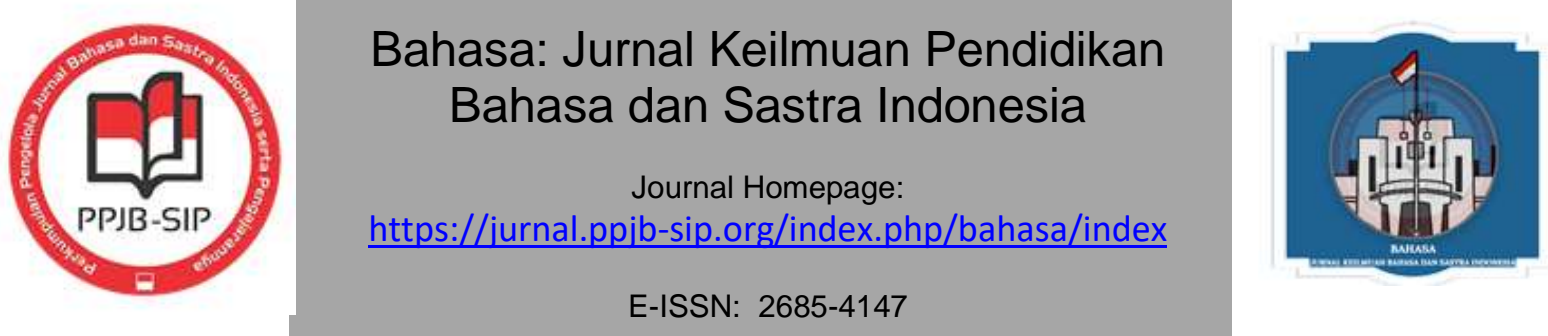

In terms of the growth or development of art education itself, it changes in the context of the expected goals and implementation of art learning. as a brief overview of these developments such as; From the perspective of history, art education that was formerly outside of school then continues or is pursued in schools, where starting from communities, studios, apprenticeships, with the term inheritance, are now also found in formal government-supported educational institutions which are interpreted as academic education for the goal of supporting child maturity.

The study of the function of art above can realize that art education in schools is a strategic part for students. If further review can also be clarified into 2, among others; the first is art in the sense of essential justification, which is art education to improve or develop students' abilities related to the problem or field of study of art itself. The second is art in the sense of contextual justification, in this case art education becomes a medium or tool to help achieve the growth and development of the personality of students. In school, the most important basic needs are the need for love and self-respect. Students who do not have the feeling that they are loved and they are capable, are less likely to have a strong learning motivation to achieve development to a higher level. For example, the search for knowledge and understanding of their own efforts or creativity and openness to new ideas which are characteristic of self-actualizing people. Students who do not believe they can be loved or are unsure of their own abilities are more likely to make safe choices

The essence of the 2 functions of art can be used as a reference in compiling a program for implementing art learning in schools. In the process, the teacher will be motivated about art and culture, but because the time is not optimal during the teaching and learning period and added to the Covid-19 atmosphere, the teacher needs to appreciate and practice art. So that art education includes aesthetic education which is very useful for students.

The essence of the 2 functions of art can be used as a reference in compiling a program for implementing art learning in schools. In the process, the teacher will be motivated about art and culture, but because the time is not optimal during the teaching and learning period and added to the Covid-19 atmosphere, the teacher needs to appreciate and practice art. So that art education includes aesthetic education which is very beneficial for students in TK Nasyatul Aisyiyah, Mungka.

Art is useful for students as a suggestion to deepen their understanding of the beautiful taste in general and art itself in particular. Expanding knowledge and perfecting understanding of the objective elements that evoke a sense of beauty in humans and the factors that influence the generation of beautiful feelings. Expanding knowledge and perfecting understanding of the subjective elements that affect the human ability to enjoy beauty. With art, students get a sense of love for national arts and culture in general, and sharpen their ability to appreciate the arts and culture of other nations that can strengthen relations between nations. 

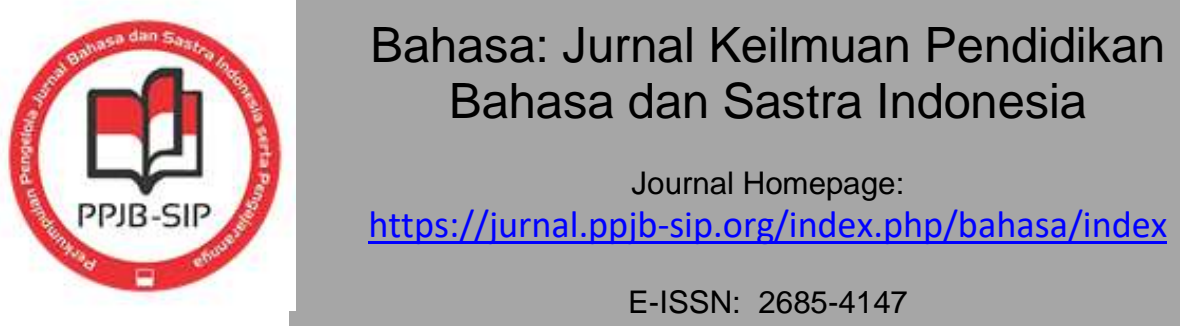

E-ISSN: $2685-4147$

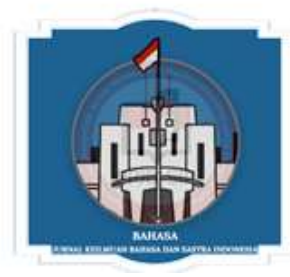

In addition, art can cultivate a refined taste in humans in general. Art can deepen the understanding of the relationship between the form of art and the life, culture and economy of society. In addition, Monday can also strengthen the ability to assess works of art and in that way indirectly develop art appreciation in society. Establish maturity of negative influences that can damage the quality of art and are harmful to the preservation of certain aspects and values of our culture. Indirectly, with the good weight that art brings, it can strengthen society in the belief in morality, humanity and divinity.

With the arts, students are able to train themselves to be disciplined in how to think and organize thoughts systematically, awakening the potential for philosophy that will make it easier to face all problems, provide broad insights and provisions for our spiritual and psychological life. Based on this, the teacher can understand the role of cultural arts in education which has a tremendous influence, even though that understanding has not been fully inspired by the teacher. Therefore, continuous and gradual training is needed so that the role of this cultural arts can be understood properly.

This ability for self-development will continue to develop and increase along with the training and willingness that is owned. So you as someone who is active should not turn off and be silent without floating anything. This is useful in competing and gaining the recognition it deserves and a stable position. Because without a solid foundation and intention, selfactualization will be created under imperfect and lame conditions. On the other hand, you will feel an achievement and a sense of satisfaction with something that you do and strive for. The appreciation for creativity will continue when you try to do your best and always develop. Without good self-control, of course, all these achievements will feel in vain.

\section{CONCLUSION}

The teacher will be motivated about art and culture, but because the time is not optimal during the teaching and learning period and coupled with the covid-19 atmosphere, the teacher needs to appreciate and practice art. So that art education includes aesthetic education which is very useful for students, especially at TK Nasyatul Aisyiyah, Mungka.

\section{REFERENCES}

Fitriani, Y. (2014). Model Pembelajaran seni musik melalui lesson study: studi kasus di SDN Jawilan, Serang. Resital: Jurnal Seni Pertunjukan (Journal of Performing Arts), 15(2), 126-138.

Gunawan, H. (2012). Pendidikan karakter. Bandung: Alfabeta, 2.

Nurgiyantoro, B. (2018). Teori pengkajian fiksi. UGM press.

Maryelliwati, M., Rahmat, W., \& Rahmad, H. A. (2020). Peristiwa, Makna dan Pengembangan Kesenian di Padangpanjang sebagai Sebuah Pelestarian. Journal Asian Community Education, 1(1), 28-36. 
Bahasa: Jurnal Keilmuan Pendidikan Bahasa dan Sastra Indonesia Vol 2 No 3 (2020) (Hal: 128 - 134)
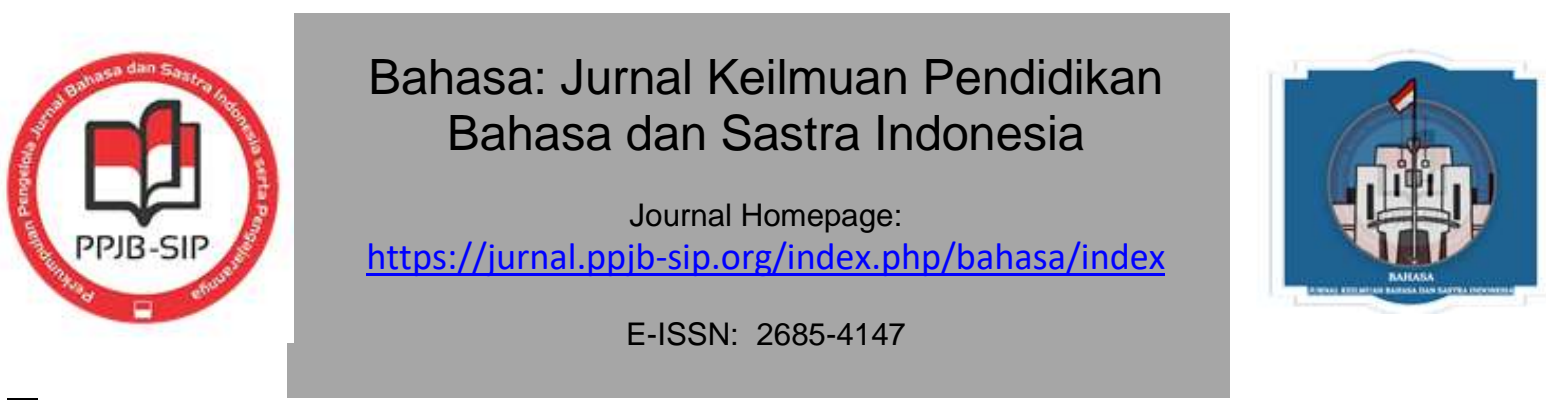

Suhaya, S. (2016). Pendidikan Seni Sebagai Penunjang Kreatifitas. JPKS (Jurnal Pendidikan dan Kajian Seni), 1(1).

Sukring, S. (2016). Pendidik dalam Pengembangan Kecerdasan Peserta Didik (Analisis Perspektif Pendidikan Islam). Tadris: Jurnal Keguruan Dan Ilmu Tarbiyah, 1(1), 57-68. 